\title{
Relevant nursing measures for the adverse reactions associated with chimeric antigen receptor T cells (CAR-T) immunotherapy: a systematic review of case reports ${ }^{\dagger}$
}

Original article

Xu Zhang ${ }^{a}$, Di Sun ${ }^{b}$, Gui-Chun Jianga,*

aDepartment of Nursing, Cancer Hospital of China Medical University, Liaoning Cancer Hospital, Shenyang, Liaoning 110042, China

${ }^{b}$ School of Nursing, Liaoning University of Traditional Chinese Medicine, Shenyang, Liaoning 110032, China

Received: 3 October 2018; Accepted: 22 December 2018; Published: 20 June 2019

Abstract: 0 objective: Cytokine release syndrome (CRS) and tumor lysis syndrome (TLS) that occur after chimeric antigen receptor T (CAR-T) cells are reinfused, which severely affect the survival and prognosis of patients. Although several articles have reported on the care of CAR-T cell immunotherapy, the quality of the study and the effectiveness of holistic nursing interventions have not been systematically reviewed. The purpose of this study was to systematically evaluate the existing holistic nursing interventions of CAR-T cell immunotherapy.

Methods: A literature search for keywords was performed in PubMed, EMBASE, the Cochrane Library, CNKI, CBM, and Wanfang Data from its inception until January 2018. Studies were deemed eligible if they comprised patients with tumor receiving CAR-T cell immunotherapy, described the holistic nursing process, and were published in Chinese and English.

Results: A total of 6 articles on holistic nursing interventions of CAR-T cell immunotherapy are reported, and the nursing methods and results of each article are analyzed. The quality of the studies included was medium. All nursing measures were considered effective. Conclusions: Holistic nursing programs reduce the incidence of CRS and TLS and improve the quality of life of cancer patients.

Keywords: chimeric antigen receptor T cells $\bullet$ immunotherapy $\bullet$ neoplasms $\bullet$ nursing

(c) Shanxi Medical Periodical Press.

\section{Introduction}

At present, tumor is one of the main causes of death in patients, and its treatment is mostly based on the comprehensive treatment such as surgery, radiotherapy,

'This project was supported by Liaoning Natural Science Foundation (No. 20180550229). and chemotherapy. However, these traditional therapies are not effective in some patients with recurrent or advanced malignant tumors. In recent years, with the continuous development of biomedicine, chimeric antigen receptor T (CAR-T) cells as a cellular immunotherapy, for patients with recurrent and advanced malignant tumors, also have an effect. The principle of CAR-T cell immunotherapy is to combine the single-chain antibody

Cited information: Zhang X, Sun D, Jiang G-C. Relevant nursing measures for the adverse reactions associated with chimeric antigen receptor T cells (CAR-T) immunotherapy: a systematic review of case reports. Front Nurs. 2019; 2: $x x-x x$. 
that recognizes a tumor-associated antigen with the activation motif of the $T$ cell. That is to say, combining the high affinity of antibody for tumor antigen with the killing mechanism of $\mathrm{T}$ lymphocyte and transfection of $T$ cells by gene transduction methods gives them the ability to specifically recognize and kill tumor cells. ${ }^{1}$ Compared with traditional chemoradiotherapy, CAR-T cell immunotherapy is characterized by low toxicity, high efficiency, and individualization. ${ }^{2}$ Although CAR-T cell immunotherapy can be widely applied to various tumors with clear tumor markers, it can effectively control tumor progression and even achieve tumor cure ${ }^{3-5}$ but there may be some adverse reactions during treatment, such as cytokine release syndrome (CRS) and tumor lysis syndrome (TLS).

CRS is a group of clinical syndromes caused by the release of numerous inflammatory mediators (such as cytokines and chemokines) by T cells, B cells, NK cells, monocytes, and macrophages after CAR-T cells are reinfused. ${ }^{6}$ These inflammatory mediators trigger an acute inflammatory response, induce epithelial and tissue damage, and lead to microvascular leakage, heart failure, and even death. CRS is one of the most common serious adverse reactions in CAR-T cell immunotherapy, which is mainly manifested as fever, hypotension, exanthema, and so on, and serious cases lead to acute respiratory distress syndrome (ARDS) or multiple organ failure. ${ }^{7}$ It usually occurs at 6-20 days after treatment, lasting for about 3 weeks, which are related to the original disease, genetic polymorphism, and the structure of the chimeric antigen receptor. ${ }^{8}$

TLS is another serious adverse reaction after CAR-T cells are reinfused. TLS is caused by a large number of tumor cells destroyed by various reasons, rapid release of intracellular substances, leading to the accumulation of metabolites. ${ }^{9}$ In clinical hyperkalemia, hyperphosphatemia, hypocalcemia, and hyperuricemia as a prominent feature, the progress of the disease can result in acute renal failure, disseminated intravascular coagulation (DIC) and serious arrhythmia. Some patients after the reinfusion of CAR-T cells may experience seizures and visual hallucinations and other neurological complications.

CRS and TLS are the most common and fatal complications after the CAR-T cells are reinfused, which is the key to the success or failure of treatment. ${ }^{10}$ Therefore, closely observing the patient's condition during CAR-T cell immunotherapy and regularly monitoring the relevant indicators are of great significance for the early prevention, early detection, and early diagnosis and are also the focus of the formulation and implementation of the nursing plan.

However, due to the current research on care related to CAR-T cells, there are more or less defects and deficiencies among various studies, which leads to limited guidance on clinical practice. Therefore, the purpose of this study was tantamount to systematically evaluate the existing holistic nursing interventions of CAR-T cell immunotherapy and to add new insights that would provide a reference for clinical nursing efforts.

\section{Methods}

\subsection{Literature search and selection}

A literature search for "CD19-specific chimeric antigen receptor," "CAR19 protein," "chimericantigen receptor T-Cell," "chimeric antigen receptor T cell immunotherapy," "CAR-T," "CART cell," "care," and "nursing" was performed in MEDLINE (PubMed), EMBASE, the Cochrane Central Register of Controlled Trials (CENTRAL), CNKI, CBMdisc, and Wanfang Data China Online Journals from its inception until January 2018.

Studies were deemed eligible if they comprised patients with malignant tumor receiving CAR-T cell immunotherapy, described the holistic nursing process, and were published in Chinese and English. Systematic review and studies with animal models were excluded.

Two reviewers independently read the documents retrieved from the database according to the inclusion and exclusion criteria. Any discrepancies were discussed and resolved by 2 reviewers through negotiation.

A total of 90 potentially related studies were retrieved. After 12 duplicates were removed, the remaining 78 studies were screened for the next step. By reviewing the abstracts and titles, 11 studies that met the inclusion criteria were identified. However, only 7 were fulltext articles, and a detailed screening was carried out on those articles. One article was excluded because it did not focus on persons. Therefore, 6 studies were included in the final review (Figure 1).

\subsection{Quality evaluation}

The quality of each article was assessed using Quality Appraisal Tool for Case Series Studies (QATCSS) developed by the Institute of Health Economics of Canada (IHE). ${ }^{11}$ The QATCSS has 20 entries, and each entry has 3 options (yes, no, and unclear) or (yes, no, and partially reported). Entries are used to evaluate the quality of design including research questions, study population, interventions, outcome measures, statistical analysis, and results in 6 areas. Considering that the scoring of items may be somewhat misleading, the QATCSS of IHE does not recommend using a scoring method, but instead gives each item the appropriate option. Appraisal quality using QATCSS was evaluated 


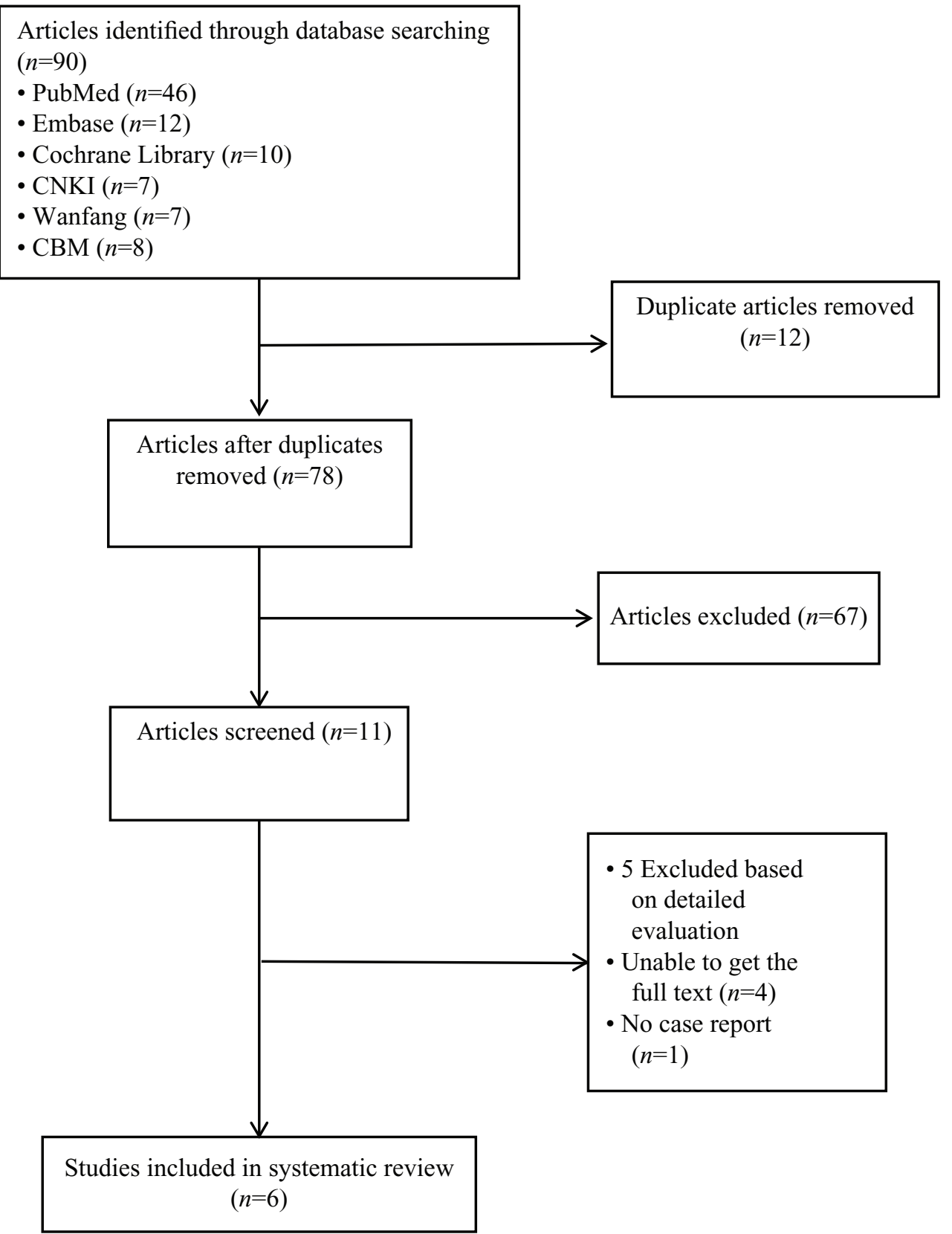

Figure 1. Flow diagram of systematic review process.

independently by 2 researchers through discussions to resolve differences.

\section{Results}

\subsection{Study characteristics}

The characteristics of the 6 studies are listed in Table 1.12-17 A total of 6 studies published between 2016 and 2017 that included 33 subjects (13 females,
20 males) assessed the nursing interventions of CAR-T immunotherapy in tumor patients. The age ranged from 2 to 61 years. All studies were conducted in China, and the study design was a case report. The cancer types included $B$ cell acute lymphoblast leukemia (B-ALL) ( $n=12)$, Hodgkin lymphoma $(n=3)$, neuroblastoma ( $n=16)$, Burkitt's lymphoma $(n=1)$, and primitive neuroectodermal tumor $(n=1)$. A variety of chemotherapeutic agents were reported, including cyclophosphamide, fludarabine, vincristine, vindesine, and cytarabine. 


\begin{tabular}{|c|c|c|c|c|c|c|c|}
\hline Authors & $\begin{array}{c}\text { Study } \\
\text { design }\end{array}$ & $\begin{array}{l}\text { Sample } \\
\text { size }\end{array}$ & Cancer type & $\begin{array}{l}\text { Treatment } \\
\text { plan }\end{array}$ & $\begin{array}{l}\text { Adverse } \\
\text { reactions }\end{array}$ & Nursing intervention & Results \\
\hline $\begin{array}{l}\text { Chen et al. } \\
2016^{14}\end{array}$ & $\begin{array}{l}\text { Case } \\
\text { report }\end{array}$ & $\begin{array}{l}N=2 \\
\text { (female) }\end{array}$ & B-ALL $(n=2)$ & $\begin{array}{l}\text { Pretreatment } \\
\text { Cycl+Flud } \\
\text { CAR-T dose } \\
50 \mathrm{~mL} \\
\left(1 \times 10^{6} / \mathrm{kg}\right)\end{array}$ & $\begin{array}{l}\text { CRS }(n=2) \\
\text { TLS }\end{array}$ & $\begin{array}{l}\text { Monitored changes in } \\
\text { temperature and blood } \\
\text { pressure } \\
\text { Monitored vital signs, } \\
\text { renal function, and } \\
\text { neurological signs, and } \\
\text { recorded output and } \\
\text { input }\end{array}$ & $\begin{array}{l}\text { CRS is controlled } \\
\text { NA }\end{array}$ \\
\hline \multirow[t]{2}{*}{$\begin{array}{l}\text { Ding et al. } \\
2017^{17}\end{array}$} & $\begin{array}{l}\text { Case } \\
\text { report }\end{array}$ & $\begin{array}{l}N=11 \\
(2 \text { females, } \\
9 \text { males })\end{array}$ & $\begin{array}{l}\text { Neuroblastoma } \\
(n=11)\end{array}$ & $\begin{array}{l}\text { Pretreatment } \\
\text { Cycl or Flud }\end{array}$ & $\begin{array}{l}\text { CRS } \\
\text { Fever }(n=10)\end{array}$ & $\begin{array}{l}\text { Physical or drug } \\
\text { cooling, and monitored } \\
\text { temperature }\end{array}$ & $\begin{array}{l}\text { Body temperature } \\
\text { returned to normal }\end{array}$ \\
\hline & & & & $\begin{array}{l}\text { CAR-T dose } \\
\text { NM }\end{array}$ & $\begin{array}{l}\text { Hypotension } \\
(n=4) \\
\text { Exanthema } \\
(n=6) \\
\text { TLS } \\
\text { Infection }(n=3) \\
\text { Pleural } \\
\text { effusion }(n=1)\end{array}$ & $\begin{array}{l}\text { Monitored blood } \\
\text { pressure and gave } \\
\text { dopamine } \\
\text { Informs the patient not } \\
\text { to scratch the skin and } \\
\text { smear calamine lotion } \\
\text { Continuous ECG } \\
\text { monitoring } \\
\text { Saline and } \\
\text { chlorhexidine gargle } \\
\text { alternate gargling } \\
\text { Oxygen inhalation, gave } \\
\text { diuretic, and recorded } \\
\text { output and input }\end{array}$ & $\begin{array}{l}\text { Blood pressure } \\
\text { returned to normal } \\
\text { after } 3 \text { days } \\
\text { After } 1 \text { week, } \\
\text { the exanthema } \\
\text { subsided. } \\
\text { NA } \\
\text { Absorbed } \\
\text { inflammation } \\
\text { remission after } \\
7 \text { days and } 5 \text { days } \\
\text { after the pleural } \\
\text { effusion }\end{array}$ \\
\hline $\begin{array}{l}\text { Feng et al. } \\
2016^{15}\end{array}$ & $\begin{array}{l}\text { Case } \\
\text { report }\end{array}$ & $\begin{array}{l}N=1 \\
\text { (female) }\end{array}$ & B-ALL $(n=1)$ & $\begin{array}{l}\text { Pretreatment } \\
\text { Cycl+Flud } \\
\text { CAR-T dose } \\
\text { NM }\end{array}$ & $\begin{array}{l}\text { Fever } \\
\text { Hypotension } \\
\text { Pain }\end{array}$ & $\begin{array}{l}\text { Gave antibiotics and } \\
\text { physical cooling } \\
\text { Monitored blood } \\
\text { pressure, and gave } \\
\text { boost medicine } \\
\text { Evaluated the nature } \\
\text { of pain and gave } \\
\text { analgesic drugs }\end{array}$ & $\begin{array}{l}\text { NM } \\
\text { NM } \\
\text { NM }\end{array}$ \\
\hline $\begin{array}{l}\mathrm{Li} \text { and } \\
\text { Wan } \\
2017^{16}\end{array}$ & $\begin{array}{l}\text { Case } \\
\text { report }\end{array}$ & $\begin{array}{l}N=9 \\
\text { (4 females, } \\
5 \text { males) }\end{array}$ & $\begin{array}{l}\text { B-ALL }(n=6) \\
\text { Hodgkin } \\
\text { lymphoma }(n=3)\end{array}$ & $\begin{array}{l}\text { Pretreatment } \\
\text { Cycl+Flud } \\
\text { CAR-T dose } \\
2 \times 10^{6} / \mathrm{kg}\end{array}$ & $\begin{array}{l}\text { Fever }(n=8) \\
\text { Hypotension } \\
(n=4) \\
\text { Hypoxemia } \\
(n=2) \\
\text { Pressure } \\
\text { ulcers }(n=1) \\
\text { Low } \\
\text { platelets and } \\
\text { hemoglobin } \\
(n=1)\end{array}$ & $\begin{array}{l}\text { Cold compress ice bag } \\
\text { for physical cooling } \\
\text { Monitored blood } \\
\text { pressure and gave } \\
\text { boost medicine } \\
\text { Oxygen inhalation } \\
\text { Turn over, massage, } \\
\text { and smear skin } \\
\text { protectant } \\
\text { Infused red blood cells } \\
\text { and platelets }\end{array}$ & $\begin{array}{l}\text { After } 6 \text { hours, } \\
\text { temperature } \\
\text { dropped to normal } \\
\text { Blood pressure } \\
\text { returned to normal } \\
\mathrm{SpO}_{2} \text { stable at } \\
95-98 \% \\
\text { After } 2 \text { days, the } \\
\text { ulcer healed } \\
\text { Hemoglobin and } \\
\text { platelets increased } \\
\text { significantly }\end{array}$ \\
\hline Yu $2017^{12}$ & $\begin{array}{l}\text { Case } \\
\text { report }\end{array}$ & $\begin{array}{l}N=7 \\
\text { (3 females, } \\
4 \text { males })\end{array}$ & $\begin{array}{l}\text { Neuroblastoma } \\
(n=5) \\
\text { Burkitt's } \\
\text { lymphoma }(n=1) \\
\text { Primitive } \\
\text { neuroectodermal } \\
\text { tumor }(n=1)\end{array}$ & $\begin{array}{l}\text { Pretreatment } \\
\text { Cycl+Flud } \\
\text { CAR-T dose } \\
\text { 10-15 mL }\end{array}$ & CRS $(n=5)$ & $\begin{array}{l}\text { Physical or drug } \\
\text { cooling, and monitored } \\
\text { temperature }\end{array}$ & $\begin{array}{l}\text { Returned to normal } \\
\text { after } 7-14 \text { days of } \\
\text { fever }\end{array}$ \\
\hline $\begin{array}{l}\text { Zhang } \\
\text { et al. } \\
2016^{13}\end{array}$ & $\begin{array}{l}\text { Case } \\
\text { report }\end{array}$ & $\begin{array}{l}N=3 \\
(1 \text { female, } \\
2 \text { males) }\end{array}$ & B-ALL $(n=3)$ & $\begin{array}{l}\text { Pretreatment } \\
\text { NM } \\
\text { CAR-T total } \\
\text { dose } 5 \times 10^{8}- \\
11 \times 10^{8}\end{array}$ & $\begin{array}{l}\text { CRS }(n=3) \\
\text { TLS } \\
\text { Hyperuricemia } \\
(n=3) \\
\text { Hyperkalemia } \\
(n=1)\end{array}$ & $\begin{array}{l}\text { Closely monitored vital } \\
\text { signs and physical or } \\
\text { drug cooling } \\
\text { Closely observed } \\
\text { changes in indicators } \\
\text { such as output and } \\
\text { input and biochemical }\end{array}$ & $\begin{array}{l}\text { Body temperature } \\
\text { dropped to normal } \\
\text { NM } \\
\text { NM }\end{array}$ \\
\hline
\end{tabular}

Note: B-ALL, B cell acute lymphoblast leukemia; CAR-T, chimeric antigen receptor T; ECG, electrocardiogram; CRS, cytokine release syndrome; TLS, tumor lysis syndrome.

Table 1. Baseline characteristics of the studies included in the systematic review. 


\subsection{Methodological quality}

The methodological quality of the study is determined by the QATCSS. Although the expert group has not yet formulated a corresponding quality-level evaluation system, it has put forward proposals to satisfy 14 or more acceptable quality. However, it is inconclusive to determine the boundary value of the level of the overall methodological quality of the case series, that is, how many items are satisfied to be high quality. The quality of the studies included is summarized in Table 2. Six studies were moderate-quality studies.

\subsection{Nursing of pretreatment chemotherapy}

Pretreatment chemotherapy can reduce the tumor burden, while removing endogenous lymphocytes, and thus enhance the antitumor effect of CAR-T cells in vivo. ${ }^{18}$ The pretreatment method was used to intravenously inject cyclophosphamide and fludarabine before the infusion of CAR-T cells. ${ }^{12,14-17}$ However, the pretreatment chemotherapy regimen may cause different degrees of myelosuppression and immunosuppression, resulting in an increased infection rate. ${ }^{19}$ Therefore, the prevention of infection is particularly important. Patients were asked to lie in laminar flow beds and sterile flow bed with chlorhexidine wipe before infusion and ultraviolet (UV) disinfection 30 minutes daily. ${ }^{14,15,17}$ Patients were informed to carry a mask, wash their mouth, and keep their mouth clean. ${ }^{14}$ Church patients and their families daily morning and evening with $0.05 \%$ chlorhexidine acetate solution of $1: 10$ (1 disinfectant:10 water) to wipe the skin of patients. ${ }^{14}$ Nursing staff should strictly carry out aseptic operation, while reducing the number of patient visits, to avoid cross-infection. ${ }^{14,17}$ Bed rest, regular review, and routine blood test prevent bleeding when platelets are low, to avoid bumping. When leukocytes are low, patients should be admitted to the laminar flow ward to give protective isolation. ${ }^{14}$

\subsection{Observation of cell reinfusion}

CAR-T cells should be given after alkalinization before reinfusion, and prepare for rescue items and medicines to prevent the occurrence of side effects such as hemolysis, allergy, and fever. The infusion line was wetted with saline before the infusion of CAR-T cells to determine venous patency. ${ }^{12,13}$ CAR-T cell suspension plus saline $50 \mathrm{~mL}$ at a rate of $30 \mathrm{gtt} / \mathrm{min}$ infusion was given, and the drop speed was adjusted to normal after 5 minutes

\begin{tabular}{|c|c|c|c|c|c|c|}
\hline Study & $\begin{array}{l}\text { Chen et al. } \\
2016^{14}\end{array}$ & $\begin{array}{c}\text { Ding et al. } \\
2017^{17}\end{array}$ & $\begin{array}{l}\text { Feng et al. } \\
2016^{15}\end{array}$ & $\begin{array}{l}\text { Li and Wan } \\
2017^{16}\end{array}$ & $\begin{array}{c}Y u \\
2017^{12}\end{array}$ & $\begin{array}{l}\text { Zhang et al. } \\
\qquad 2016^{13}\end{array}$ \\
\hline $\begin{array}{l}\text { Is the hypothesis/aim/objective of the study clearly } \\
\text { stated? }\end{array}$ & Yes & Yes & Yes & Yes & Yes & Yes \\
\hline $\begin{array}{l}\text { Are the characteristics of the participants included in the } \\
\text { study described? }\end{array}$ & Yes & Yes & Yes & Yes & Yes & Yes \\
\hline Were the cases collected in more than one center? & No & No & No & No & No & No \\
\hline $\begin{array}{l}\text { Are the eligibility criteria for entry into the study clearly } \\
\text { stated? }\end{array}$ & No & Yes & No & No & $\begin{array}{l}\text { Partially } \\
\text { reported }\end{array}$ & No \\
\hline Were participants recruited consecutively? & Unclear & Unclear & Unclear & Unclear & Yes & Unclear \\
\hline $\begin{array}{l}\text { Did participants enter the study at a similar point in the } \\
\text { disease? }\end{array}$ & Yes & Yes & Yes & Yes & Yes & Yes \\
\hline Was the intervention of interest clearly described? & Yes & Yes & Yes & Yes & Yes & Yes \\
\hline $\begin{array}{l}\text { Were additional interventions (co-interventions) reported } \\
\text { in the study? }\end{array}$ & Yes & Yes & Yes & Yes & Yes & Yes \\
\hline Are the outcome measures established a priori? & Yes & Yes & No & Yes & Yes & No \\
\hline $\begin{array}{l}\text { Were the relevant outcomes measured with appropriate } \\
\text { objective and/or subjective methods? }\end{array}$ & Yes & Yes & Yes & Yes & Yes & Yes \\
\hline $\begin{array}{l}\text { Were the relevant outcomes measured before and after } \\
\text { the intervention? }\end{array}$ & Yes & No & Yes & No & No & Yes \\
\hline $\begin{array}{l}\text { Were the statistical tests used to assess the relevant } \\
\text { outcomes appropriate? }\end{array}$ & Unclear & Unclear & Unclear & Unclear & Unclear & Unclear \\
\hline Was the length of follow-up reported? & No & No & No & No & No & No \\
\hline Was the loss to follow up reported? & Yes & Yes & Yes & Yes & Yes & Yes \\
\hline $\begin{array}{l}\text { Does the study provide estimates of the random } \\
\text { variability in the data }\end{array}$ & No & No & No & No & No & No \\
\hline
\end{tabular}

Table 2. Assessment of the quality of case report included in the present study. 
without adverse reaction. ${ }^{14,15}$ Or CAR-T cell suspension for $10-15 \mathrm{~mL}$ were slowly injected into the syringe murphy tube, the drop speed was controlled at 15-20 gtt/ min. ${ }^{12}$ The infusion process cannot be replaced by infusion pump control speed, because the infusion pump uses the way of extrusion to control the speed of the infusion, which will cause damage to the CAR-T cells. ${ }^{12}$ After completing the infusion (about 10 minutes), the residual cells with saline were repeatedly rinsed to ensure that the cells are completely imported. ${ }^{12-15}$ The patient's blood oxygen saturation, blood pressure, heart rate, and respiratory changes were closely monitored, ${ }^{12-15}$ the attention was paid to observe the patient's accompanying symptoms, such as itchy skin, suffocation, and other symptoms.

\subsection{Care of CRS}

CRS is a kind of toxic side effect that can occur after the infusion of natural and bispecific antibodies. Recently, it was found that CRS can also occur after cancer patients receiving $\mathrm{T}$ cell immunotherapy.

\subsubsection{Fever}

Fever is an iconic symptom of CRS. It was reported from 6 articles that a total of 29 patients out of 33 patients suffered from fever. ${ }^{12-17}$ Four to 11 days after reinfusion, the patients had different degrees of fever, and the temperature fluctuated at $37.5-40.2^{\circ} \mathrm{C}$. The measure of care was to closely monitor changes in body temperature after cell reinfusion. ${ }^{12-14,17}$ Patients were encouraged to drink more water during fever. ${ }^{12,15,17}$ Low heat gives physical cooling, such as a cold compress and warm sponge bath. ${ }^{12,13,15-17}$ When the body temperature is higher than $38^{\circ} \mathrm{C}$, the nurse should immediately inform the doctor and gives the patient oral antipyretic medicine according to the doctor's advice. ${ }^{12-15,17}$ When the patient's clothes are sweaty, the clothes should be replaced to maintain the dry and clean skin. ${ }^{17} \mathrm{~A}$ sudden drop in body temperature, appearing symptoms of pale and cold limbs, warming measures should be taken immediately. ${ }^{17}$ Body temperature was measured every hour and recorded. ${ }^{12-14,17}$ After a series of nursing interventions, 27 patients' body temperature dropped to normal within a week and 2 patients recovered to normal after 2 weeks of nursing.

\subsubsection{Hypotension}

The total number of patients with hypotension was 9 from 3 articles. ${ }^{15-17}$ Blood pressure was monitored closely, and blood pressure was measured every 30 minutes in the presence of signs of hypotension (headache, dizziness, weakness, fast heart rate, dyspnea, cold limbs, etc.). ${ }^{15,17}$
Patients with or without irritability or slow, pale or cyanosis, cold limbs, pulse fast and weak, and decreased urine output and other symptoms of shock were closely observed. ${ }^{15,17}$ According to the doctor's advice to give open venous access and infusion of saline to expand blood volume, or continuous pump of vasoactive drugs (dopamine), patients were given oxygen, until the blood pressure recovered..$^{15-17}$ The urine volume per hour was recorded in detail, and the change in urine volume was found timely. ${ }^{17}$ All patients referred returned to normal blood pressure within 3 days.

\subsubsection{Exanthema}

Only 1 article reported care of exanthema in 6 patients. ${ }^{17}$ Among them, 1 patient had a scattered exanthema on the 1st day after CAR-T cell reinfusion and resolved spontaneously after 1 day. The exanthema occurred in 3 patients after 3,10 , and 12 days, and 2 patients developed exanthema after 22 days. In 2 patients, the exanthema scattered only on the facial area, and exanthema in 4 patients scattered throughout the body. To keep patient's clothes dry and comfortable, nails should be cut often. Patients and their families were instructed not to scratch the exanthema with their hands and ask younger patients to wear small gloves to prevent scratching the skin and infection. Patients who feel itchy were given calamine lotion smear and asked to apply 3-4 times a day. After 1 week, the exanthema subsided.

\subsection{Nursing of TLS}

Three articles reported nursing of patients with TLS ${ }^{13,14,17}$ but only 3 patients in 1 article had TLS. ${ }^{13}$ Hyperuricemia was found in 3 patients, and among them, 1 patient developed hyperkalemia at the same time, but none developed acute renal failure, arrhythmia, DIC, and neurological disease. A 24-hour continuous electrocardiogram (ECG) monitoring was given to monitor the changes of heart rate, respiration, and blood pressure, and it was recorded in time accurately. The patient's 24-hour intake and output were strictly recorded. Routine blood test, liver and kidney function, electrolytes, and ECG were daily reviewed, and changes in indicators were observed. Whether there are seizures, hallucinations, or other nervous system symptom abnormalities was closely observed.

\section{Discussion}

The systematic review reviewed the holistic nursing approach to CAR-T immunotherapy and provided new insights into nursing interventions. The nursing measures included in the study were considered effective. 
In addition, the quality of the study was evaluated using QATCSS. The purpose of the study, study population, interventions, outcome measures, and utility were fully considered. In the systematic review, the overall quality of the 6 studies was modest, and the results of highquality research still needed to be applied in clinical practice.

Currently, CAR-T cell immunotherapy technology is becoming ever more mature, but there are still some unclear issues, such as optimal infusion dose and safety. The results showed that low-dose $\left(1 \times 10^{5} / \mathrm{kg}\right)$ CAR-T cells were safe and effective in 42 patients with refractory and/or relapsed B-ALL. ${ }^{20}$ Ninety percent of patients achieved complete remission, with only mild or mild-to-moderate CRS reported in most patients. Another study showed infused $10^{6} \mathrm{CAR}-\mathrm{T}$ cells in 45 children and young patients with refractory and/or relapsed B-ALL, without showing toxic brain edema and death. The remission rate of minimal residual disease (MRD) was 93\%. ${ }^{21}$ Twenty-three percent of patients developed reversible CRS and/or reversible neurotoxicity. At present, there is still a lack of relevant data to prove that there is a clear correlation between the dose of CAR-T cells and the therapeutic response or toxicity, and the best curative dose is still lacking in uniform regulation. This is likewise a major safety problem in the clinical application of CAR-T cell immunotherapy. Because of this, when nursing staff infused CAR-T cells for patients, we should closely observe the changes of vital signs and the occurrence of related complications and take timely and effective nursing measures to guarantee the safety of patients.

For the first case of patients treated with CAR-T cells, nurses need to closely observe the changes in the condition, so nursing work should face a huge challenge. ${ }^{22}$ Studies have shown that multi-disciplinary teams (MDTs) are important for disease treatment and care. ${ }^{23}$ Contact with the department of nephrology, cardiology and laboratory and other multidisciplinary to jointly formulate a rescue and treatment plan. We established a special nursing team of head nurse - head - responsible nurse, all learning CAR-T cell immunotherapy and complications of care, set down a complications care plan. We developed CRS clinical grade observation table, which is easy to observe the disease and used in early detection of complications. The nursing staff should regularly participate in the discussion of the medical records of the doctor group, understand the process of treatment and the progress of the disease in time, and make the appropriate preparation for nursing.

The 6 articles reported the nursing of CAR-T before infusion, during infusion, and adverse reaction after infusion, but most of them ignored the psychological nursing of the patients. It is reported that the psychological status and quality of life of the patients with malignant tumors are important factors affecting their health. ${ }^{24}$ In patients treated with CAR-T cells before and after treatment, there will be varying degrees of stress, anxiety, and other negative emotions, especially when patients with persistent fever and blood pressure and other discomfort; individual patients will show the extreme emotional decline, which will affect the therapeutic effect. Therefore, nursing staff needs patience to communicate for the patient's condition and the necessary psychological guidance. The psychological nursing measures for the patients treated with CAR-T cell immunotherapy include the following: (1) Setting up a patient-centered holistic nursing concept; establishing a favorable nursepatient relationship and providing a clean, quiet, and comfortable environment. (2) Patients of different age, character, culture, economic status, and social background have different psychological needs and should be given personalized psychological care. (3) Communicating with patients and their families to improve their understanding and correct understanding of CAR-T treatment. Timely counseling for bad emotions alleviating the psychological burden on patients and reduce negative emotions. (4) Patients should be given care, respect, encouragement, and support to enhance their confidence. (5) Maintaining the patient's stable condition, reduce patient pain and anxiety, and make the patient better cooperate with the treatment. (6) Doing a good job to the patient's family members, giving patients love, understanding, and tolerance. (7) Emphasizing the help of social forces to help patients relieve from the economic pressure.

Correct discharging guide contributes to functional rehabilitation of patients and improvement of quality of life. After CAR-T treatment, the blood routine tests were repeated twice a week until the results became normal. Blood samples were taken periodically after CAR-T cells were infused at home, and tumor markers were monitored. Bone marrow and imaging examinations were carried out regularly to determine the level of CAR-T cells in the body. Patients were informed with symptoms such as fever, hypotension, exanthema, and dyspnea during home stay and asked to visit hospital in time for treatment. When taking care not to use hormone drugs, until the blood CAR-T cells disappeared. Reasonable arrangements were made for daily diet, to avoid cold and influenza. Proper outdoor exercise was encouraged in order to enhance the body immunity, but strenuous physical activities were discouraged.

\section{Conclusions}

CRS and TLS are the most common and fatal complications after CAR-T cells are reinfused, which is the key 
to the success or failure of treatment. Therefore, holistic nursing of patients treated with CAR-T cell immunotherapy is important. The results of this systematic review show that holistic nursing programs reduce the incidence of CRS and TLS and improve the quality of life of cancer patients. It is recommended to develop a special care plan, while not ignoring the patient's psychological care.

\section{Limitations}

This systematic review has certain some limitations. We only included articles published in Chinese and the full text of English articles was not available, which could lead to publication bias. The overall quality of these articles is medium, and no high-quality articles were discovered. Therefore, the results of high-quality research are still needed to apply in clinical practice.

\section{Implications for practice}

Before and after CAR-T cells infusion to develop a suitable special care plan is necessary. Finally, the patient's psychological care should also be considered.

\section{Conflicts of interest}

All contributing authors declare no conflicts of interest.

\section{References}

1. Ramos CA, Dotti G. Chimeric antigen receptor (CAR)-engineered lymphocytes for cancer therapy. Expert Opin Biol Ther. 2011;11:855-873.

2. Firor $A E$, Jares $A, M a Y$. From humble beginnings to success in the clinic: chimeric antigen receptor-modified T-cells and implications for immunotherapy. Exp Biol Med (Maywood). 2015;240:1087-1098.

3. Porter DL, Levine BL, Kalos M, Bagg A, June $\mathrm{CH}$. Chimeric antigen receptor-modified $\mathrm{T}$ cells in chronic lymphoid leukemia. $N$ Engl $J$ Med. 2011;365:725-733.

4. Zhu Y, Tan Y, Ou R, et al. Anti-cd19 chimeric antigen receptor-modified $T$ cells for $b$-cell malignancies: $a$ systematic review of efficacy and safety in clinical trials. Eur J Haematol. 2016;96:389-396.

5. Maude SL, Frey N, Shaw PA, et al. Chimeric antigen receptor $\mathrm{T}$ cells for sustained remissions in leukemia. N Engl J Med. 2014;371:1507-1517.

6. Lee DW, Gardner R, Porter DL, et al. Current concepts in the diagnosis and management of cytokine release syndrome. Blood. 2014;124:188-195.

7. Grupp SA, Kalos M, Barrett D, et al. Chimeric antigen receptor-modified $\mathrm{T}$ cells for acute lymphoid leukemia. N Engl J Med. 2013;368:1509-1518.

8. Maus MV, Grupp SA, Porter DL, June $\mathrm{CH}$. Antibody-modified $T$ cells: cars take the front seat for hematologic malignancies. Blood. 2014;123:2625-2635.

9. Kochenderfer JN, Dudley ME, Carpenter RO, et al. Donor-derived cd19-targeted T cells cause regression of malignancy persisting after allogeneic hematopoietic stem cell transplantation. Blood. 2013;122:4129-4139.

10. Ke $X Y$. Application progress of chimeric antigen receptor - $\mathrm{T}$ cell immunotherapy in hematological malignancies. Chin General Med. 2016;19:13611366 (in Chinese).

11. Moga C, Guo B, Schopflocher D. Development of a Quality Appraisal Tool for Case Series Studies Using a Modified Delphi Technique. Vol. 25. Edmonton AB: Institute of Health Economics; 2012:1262-1268.

12. Yu LL. Nursing care of 7 children with advanced malignant solid tumor treated with CAR-T cell combined with chemotherapy. Tianjin Nurs. 2017;25:528-529 (in Chinese).

13. Zhang $P$, Dai JX, Zhou L. Nursing care of patients with relapsed and refractory hematological malignancies undergoing CART cell therapy. Med Inf. 2016;29:226-227 (in Chinese).

14. Chen XL, Feng YM, Zeng YJ, et al. Exploration of integrated nursing care on CAR-T cell immunotherapy for refractory acute lymphocytic leukemia. Chin J Blood Transfusion. 2016;29:1104-1107 (in Chinese).

15. Feng N, Du X, Zhang C, Hao J, Zeng L. Nursing care of patients with recurrent refractory acute lymphoblastic leukemia treated with chimeric antigen receptor. Chongqing Med. 2016;45:140-141 (in Chinese).

16. Li LN, Wan Y. Nursing care of patients with B cell malignant tumor treated with chimeric antigen receptor modified $\mathrm{T}$ cell immunotherapy. Chin $\mathrm{J}$ Nurs. 2017;52:297-299 (in Chinese).

17. Ding YG, Zhao W, Wu XY, Ma XL. Nursing experience of children with neuroblastoma developing adverse reaction after retransfusion of chimeric antigen receptor-transduced T-cells. Chin J Nurs. 2017;52:307-310 (in Chinese).

18. Turtle CJ. Chimeric antigen receptor modified $T$ cell therapy for B cell malignancies. Int $J$ Hematol. 2014;99:132-140. 
19. Yamauchi K, Yang M, Hayashi K, et al. Induction of cancer metastasis by cyclophosphamide pretreatment of host mice: an opposite effect of chemotherapy. Cancer Res. 2008;68:516-520.

20. Pan J, Yang JF, Deng BP, et al. High efficacy and safety of low-dose cd19-directed CAR-T cell therapy in 51 refractory or relapsed b acute lymphoblastic leukemia patients. Leukemia. 2017;31:2587-2593.

21. Gardner RA, Finney O, Annesley C, et al. Intent to treat leukemia remission by cd19car $T$ cells of defined formulation and dose in children and young adults. Blood. 2017;129:3322-3331.
22. Mol MM, Boeter GW, Verharen L, Kompanje EJ, Bakker J, Nijkamp MD. Patient- and family-centered care in the intensive care unit, a challenge in the daily practice of healthcare professionals. J Clin Nurs. 2016;26:3212-3223.

23. Thuy NL, Clemenceau AL, Lebaron VT. Challenges encountered by Vietnamese nurses when caring for patients with cancer. Oncol Nurs Forum. 2017;44:147-151.

24. Morsch CM, Gonçalves LF, Barros E. Health-related quality of life among haemodialysis patients - relationship with clinical indicators, morbidity and mortality. J Clin Nurs. 2006;15:498-504. 